\title{
STAMINA OF A GASKETED BOLTED FLANGED PIPE JOINT UNDER DYNAMIC LOADING
}

\author{
Muhammad AbID ${ }^{1}$, AtTa UR Rehman ShaH ${ }^{* 2}$ ANd Hafiz Abdul WaJID ${ }^{3,4}$ \\ ${ }^{I}$ Interdisciplinary Research Center, COMSATS Institute of Information Technology, \\ Wah Cantt, Pakistan. \\ ${ }^{2}$ Department of Mechanical Engineering, HITEC University, Taxila, Pakistan. \\ ${ }^{3}$ Department of Mathematics, COMSATS Institute of Information Technology, \\ Lahore, Pakistan. \\ ${ }^{4}$ Department of Electrical Engineering, Islamic University Medina, Kingdom of Saudi Arabia. \\ *corresponding author: atta85@engineer.com \\ (Received: $1^{\text {st }}$ Jun. 2015; Accepted: 25th Mar. 2016; Published on-line: 30th Nov. 2016)
}

\begin{abstract}
Gasketed bolted flange joints are the most critical components in pipelines for their sealing and strength under operating conditions. Most of the work available in literature is under static loading, whereas in industry, cyclic loads are applied due to the vibrating machinery such as motors, pumps, sloshing in offshore applications and in the ships etc. In this study a three dimensional finite element analysis of a gasketed joint is carried out using a spiral wound gasket under bolt up and dynamic operating conditions (internal pressure, axial and bending) singly and in combination. The cyclic axial loads are concluded relatively more challenging for both the sealing and strength of the joint. Higher magnitudes of loads and frequencies are also observed more challenging to the joints performance.
\end{abstract}

ABSTRAK: Sendi bebibir yang bergasket dan bolt adalah komponen paling kritikal dalam saluran paip bagi pengedapan dan kekuatan mereka di dalam keadaan operasi. Kebanyakan kajian yang sedia ada dalam sastera adalah di bawah pembebanan statik, sedangkan dalam industri, beban kitar digunakan untuk jentera bergetar seperti motor, pam, sloshing dalam aplikasi luar pesisir dan dalam kapal dan lain-lain. Dalam kajian ini analisis elemen finite tiga dimensi bagi sendi bergasket dijalankan menggunakan gasket bergelendong spiral dalam keadaan operasi yang dinamik (tekanan dalaman, bersama paksi dan lentur) secara tunggal dan dalam kombinasi. Beban paksi kitaran diselesaikan dalam keadaan lebih mencabar bagi pengedapan dan kekuatan sendi. Magnitud yang tinggi dari beban dan frekuensi juga didapati lebih mencabar kepada prestasi sendi.

KEYWORDS: grid-connected PV system; power electronic interface; modeling; control

\section{INTRODUCTION}

Gasketed pipe flange joints are widely used to connect pipe-to-pipe or pipe-to-otherequipment in industries including nuclear, petrochemical, processing, pressure vessels, and piping industries etc. These joints are considered to be the weakest elements (in terms of sealing and strength) in many industrial applications. Most of the previous work is limited to bolt up, internal pressure, and static external loading only, but the actual conditions of the industry are dynamic in nature. These dynamic loads may be applied by various vibrating machinery like pumps, motors, and gear machinery. Vibrations may also be due to sloshing effects and offshore applications. These dynamic conditions are the actual risk to the strength and sealing capability of the pipe joints. A limited amount of work is 
available in literature [1-10] focusing on the dynamic behavior of gasketed bolted pipe joints but no research has yet been observed to address these issues. In a gasketed pipe flange joint, problems of strength, bolt scatter, bolt bending, and joint relaxation are observed even during bolt-up; resulting in the flange rotation and gasket crushing. Under applied operating conditions, the performance worsens under bolt-up plus harmonic axial loading.

In the present study, a three dimensional finite element analysis of a gasketed pipe flange joint is carried out using a Spiral Wound Gasket (SWG) under bolt-up, internal pressure, and harmonically applied external loads (Axial and Bending); these are given in Table 1. Variable loading magnitudes applied are selected based on the steady state analysis given in reference [11]. Frequencies of loads applied are chosen on the basis of available pumps [12]. A Flange joint of four-inch $900 \#$ class is used in the present study.

Table 1: Loading conditions

\begin{tabular}{|c|c|c|c|}
\hline Sr. \# & Loading & Type of loading & Load \\
\hline 1 & Bolt-up & ASME bolt up strategy & Torque $=700 \mathrm{Nm}$ \\
\hline \multirow[t]{5}{*}{2} & $\begin{array}{l}\text { Harmonic } \\
\text { loadings }\end{array}$ & Harmonic axial loading only & $\begin{array}{l}\mathrm{AL}=100 \sim 650 \mathrm{kN} \\
\mathrm{FRQ}=30 \sim 60 \mathrm{~Hz}\end{array}$ \\
\hline & & Harmonic bending loading only & $\begin{array}{l}\mathrm{BL}=10 \sim 25 \mathrm{kNm} \\
\mathrm{FRQ}=30 \sim 60 \mathrm{~Hz}\end{array}$ \\
\hline & & $\begin{array}{l}\text { Design pressure plus harmonic axial } \\
\text { loadings }\end{array}$ & $\begin{array}{l}\mathrm{DP}=15.3 \mathrm{MPa} \\
\mathrm{AL}=100 \sim 650 \mathrm{kN} \\
\mathrm{FRQ}=30 \sim 60 \mathrm{~Hz}\end{array}$ \\
\hline & & $\begin{array}{l}\text { Design pressure plus harmonic bending } \\
\text { loadings }\end{array}$ & $\begin{array}{l}\mathrm{DP}=15.3 \mathrm{MPa} \\
\mathrm{BL}=10 \sim 25 \mathrm{kNm} \\
\mathrm{FRQ}=30 \sim 60 \mathrm{~Hz}\end{array}$ \\
\hline & & $\begin{array}{l}\text { Design pressure plus combined harmonic } \\
\text { axial plus bending loadings }\end{array}$ & $\begin{array}{l}\mathrm{DP}=15.3 \mathrm{MPa} \\
\mathrm{AL}=525 \mathrm{kN} \\
\mathrm{BL}=10 \sim 20 \mathrm{kNm} \\
\mathrm{FRQ}=30 \sim 60 \mathrm{~Hz}\end{array}$ \\
\hline
\end{tabular}

\section{FINITE ELEMENT MODELING, MESHING}

\subsection{Modeling and Meshing}

A complete 360-degree model of the flange joint, developed by [11], is modified and used as shown in Fig. 1. Due to the symmetry of the geometry and loading conditions, half the thickness of the gasket is modeled. A pipe of $330 \mathrm{~mm}$ length is modeled with the flange. Keeping in view the symmetry of the joint, only one side of the joint is used. Commercial FEA software ANSYS [13] is used during the analysis.

A SOLID45 structural element is used to model the flange, bolt, gasket and pipe; three-dimensional 'surface-to-surface' CONTA174 contact elements, in combination with TARGE170 target elements are used between the flange face and gasket, bolt shank and flange hole, the top of the flange, and the bottom of the bolt in order to simulate contact distribution for both structural and thermal models. A 3-D interface element INTER195 is used as a special gasket element for meshing of the spiral wound gasket, which is compatible with SOLID45 structural elements. The gasket meshing requires two faces i.e. 
source and target faces. The source face which is the top area of the gasket is meshed with SHELL 63 elements. The FE model used is already validated by [11] under static internal pressure loading.

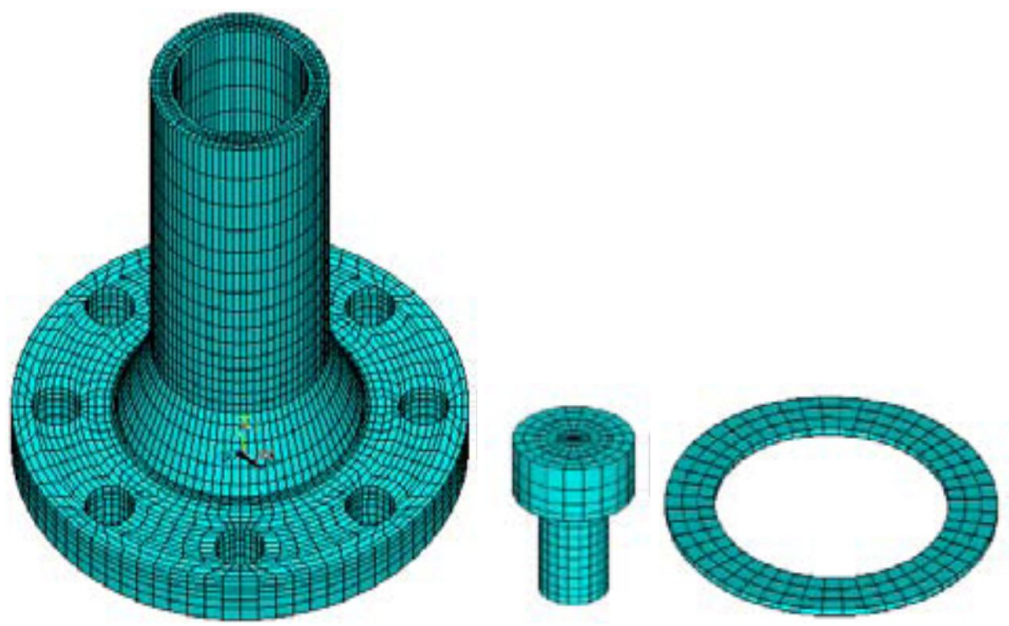

Fig. 1: Modeling and meshing of flange, bolt and gasket.

\subsection{Material Properties}

Allowable stresses and material properties for the flange, pipe, and bolt are given in Table 2 [14]. Bilinear elastoplastic material is used for the flange and bolts. Non-linear material behavior of the spiral wound gasket is defined using a simplified approach [15].

Table 2: Material properties

\begin{tabular}{ccccc}
\hline Parts & As per code & $\begin{array}{c}\text { Young's modulus } \\
(\mathbf{M P a})\end{array}$ & $\begin{array}{c}\text { Poisson's } \\
\text { ratio }\end{array}$ & $\begin{array}{c}\text { Allowable stress } \\
(\mathbf{M P a})\end{array}$ \\
\hline $\begin{array}{c}\text { Flange/pipe } \\
\text { Bolt }\end{array}$ & ASTM A350 LF2 & 173058 & 0.3 & $248.2\left(2 / 3^{\text {rd }} \sigma_{\mathrm{Y}}\right)$ \\
\hline
\end{tabular}

\section{BOUNDARY CONDITIONS}

Bolt-up: Bolts are constrained in the radial and tangential directions and are free to elongate in the axial direction. During bolt tightening, displacement is applied at the bottom of the bolts to achieve target stress. ASME bolt-up strategy is used to tighten the bolts [16]. The variable loading magnitudes applied are selected based on the steady state analysis given in reference [11].

Contact Initiation: The contact is initiated between the flange face and the bottom of the bolt and between the flange raised face bottom and the gasket top surface by applying a sufficiently small displacement at the bottom of the bolts (UY=-0.01 mm) such that it must not produce stress in the joint components.

Pre-stress or bolt-up: Target stress in the bolts is achieved by applying a second value of displacement in sequence at the bottom of the bolts. 
Harmonic axial loading: After bolt-up, external axial loads $(100 \sim 650 \mathrm{kN})$ with different cyclic frequencies (30 60 Hz i.e. 1800 3600 RPM) are applied to analyze the joint behavior.

Internal pressure plus harmonic axial loading: After bolt-up, static design pressure is applied and then harmonic axial loads $(100 \sim 650 \mathrm{kN})$ with different cyclic frequencies (30 60 Hz) are applied.

Harmonic bending loading: After bolt-up, harmonic bending loads $(10 \sim 25 \mathrm{kNm})$ with different cyclic frequencies $(30 \sim 60 \mathrm{~Hz})$ are applied to analyze the joint behavior.

Internal pressure plus harmonic bending loading: After bolt-up, static design pressure is applied and then harmonic bending loads $(10 \sim 25 \mathrm{kNm})$ with different cyclic frequencies (30 60 Hz) are applied.

Internal pressure plus combination of harmonic axial loading plus harmonic bending loading: After bolt-up, static design pressure is applied and then combined harmonic axial loading $(525 \mathrm{kN})$ plus harmonic bending loads $(10 \sim 20 \mathrm{kNm})$ with different cyclic frequencies $(30 \sim 60 \mathrm{~Hz})$ are applied.

Applied boundary conditions are shown in Fig. 2(a).

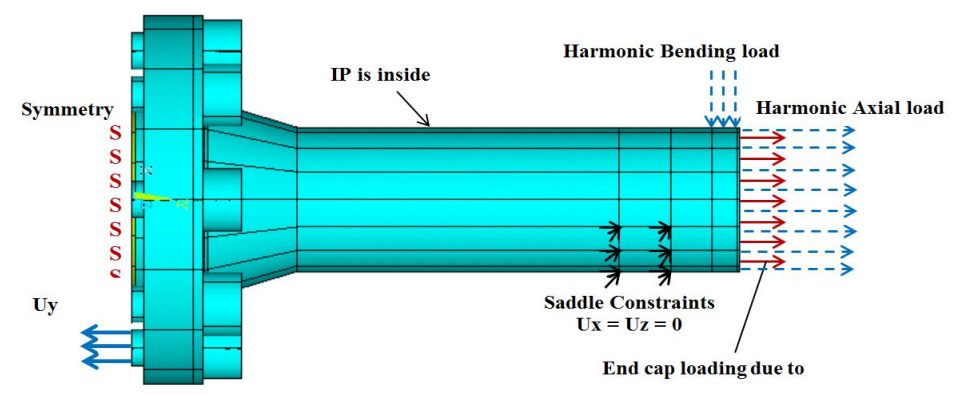

(a)

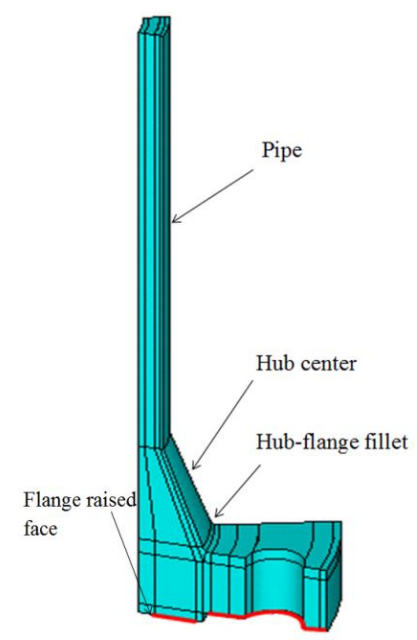

(b)

Fig. 2: (a) Boundary conditions (b) Flange quarter model showing different locations of stress measurement. 


\section{RESULTS AND DISCUSSIONS}

Results are taken at different locations in the joint including the pipe, hub center, hubflange fillet, bolts and gasket. Some of the locations are tagged in Fig. 2(b).

\subsection{Pipe and Hub Center}

Stress variation at the pipe and hub center is observed within the yield limit of the pipe and flange material at all locations under all loadings and frequencies.

\subsection{Hub Flange Fillet}

The hub flange fillet is a critical location since principal stress and stress intensity values have exceeded the yield stress limit of the flange material even at bolt-up.

\subsubsection{Harmonic axial loading only}

Figure 3 shows stress results at the hub flange fillet location under harmonic axial loading. Axial stress has crossed the yield limit of the flange material at $400 \mathrm{kN}$ and 525 $\mathrm{kN}$ axial loads at $30 \mathrm{~Hz}$ and $60 \mathrm{~Hz}$ frequencies respectively. The value of the stress is observed to be increasing with increase in harmonic axial loading. The maximum axial stress at the hub-flange fillet has increased from $228 \mathrm{MPa}$ at bolt-up to $262 \mathrm{MPa}(15 \%)$ and $279 \mathrm{MPa}(22 \%)$ at maximum axial load of $650 \mathrm{kN}$ acting with a harmonic frequency of 30 $\mathrm{Hz}$ and $60 \mathrm{~Hz}$ respectively. The maximum value of stress intensity at the hub-flange fillet has increased from $269 \mathrm{MPa}$ at bolt-up to $310 \mathrm{MPa}(15 \%)$ and $322 \mathrm{MPa}(20 \%)$ at maximum axial load of $650 \mathrm{kN}$ acting with a harmonic frequency of $30 \mathrm{~Hz}$ and $60 \mathrm{~Hz}$ respectively. Increase in the value of SY and SINT at $650 \mathrm{kN}$ axial load, is respectively $7 \%$ and $5 \%$ greater with the cyclic frequency of $60 \mathrm{~Hz}$ rather than $30 \mathrm{~Hz}$. The increase in cyclic frequency has some effects on the stresses value at the hub flange fillet location while the increase in magnitude of the axial load is causing significant increase in the stresses.

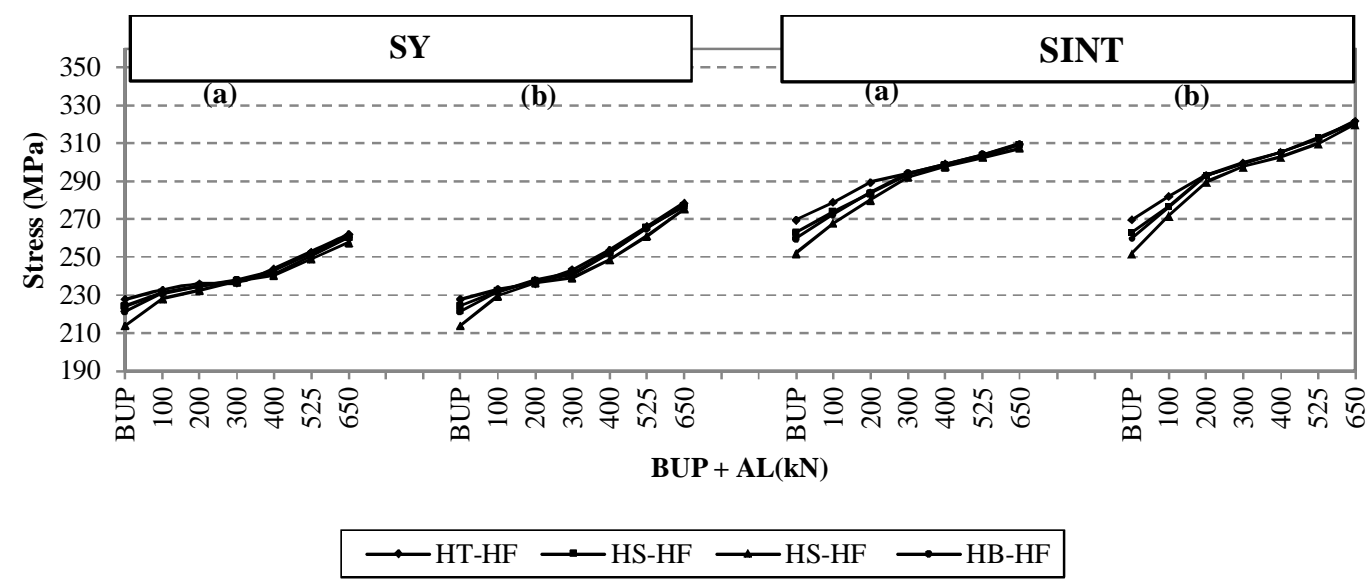

Fig. 3: Stresses (SY and SINT) results at the hub flange fillet under BUP and harmonic axial loading (100 650 kN) of frequency: (a) $30 \mathrm{~Hz}$, (b) $60 \mathrm{~Hz}$.

\subsubsection{Internal Pressure plus Harmonic Axial Loading}

Figure 4 shows stress results at the hub flange fillet location under combined design pressure and harmonic axial loading. Axial stress has crossed the yield limit of the flange 
material at $400 \mathrm{kN}$ at both the frequencies. The value of the stress is observed to be increasing with the application of design pressure and with the increase in harmonic axial loading and frequencies. The maximum axial stress at hub-flange fillet has increased from $228 \mathrm{MPa}$ at bolt-up to $272 \mathrm{MPa}(19.2 \%)$ and $273 \mathrm{MPa}(19.7 \%)$ at maximum axial load of $650 \mathrm{kN}$ acting with harmonic frequency of $30 \mathrm{~Hz}$ and $60 \mathrm{~Hz}$ respectively. The maximum value of the stress intensity at the hub-flange fillet has increased from $269 \mathrm{MPa}$ at bolt-up to $317 \mathrm{MPa}(18 \%)$ and $319 \mathrm{MPa}(18.5 \%)$ at maximum axial load of $650 \mathrm{kN}$ acting with harmonic frequency of $30 \mathrm{~Hz}$ and $60 \mathrm{~Hz}$ respectively. The increase in the value of SY and SINT at $650 \mathrm{kN}$ axial load is $0.5 \%$ greater with the cyclic frequency of $60 \mathrm{~Hz}$ rather than $30 \mathrm{~Hz}$. The increase in the cyclic frequency has negligible effect on the results in this case because the static internal pressure provides damping to the structure, whereas the increase in magnitude of the axial load significantly caused an increase in the stresses.

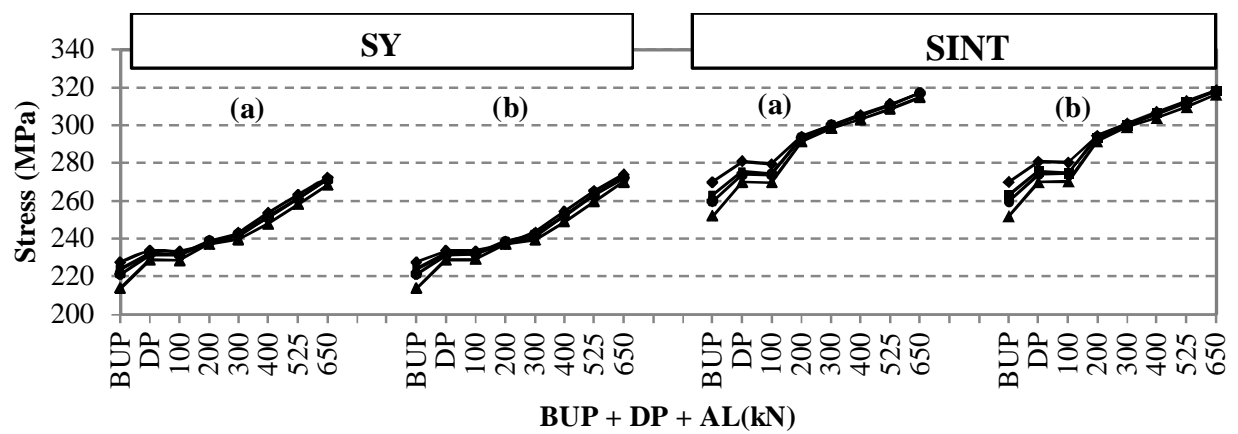

\begin{tabular}{|c|c|c|c|}
\hline$\longrightarrow$ HT-HF & $\longrightarrow \mathrm{HS}-\mathrm{HF}$ & $\longrightarrow \mathrm{HS}-\mathrm{HF}$ & $\longrightarrow$ HB-HF \\
\hline
\end{tabular}

Fig. 4: Stresses (SY and SINT) results at the hub flange fillet under BUP, DP and harmonic axial loading (100 650 kN) of frequency: (a) $30 \mathrm{~Hz}$, (b) $60 \mathrm{~Hz}$.

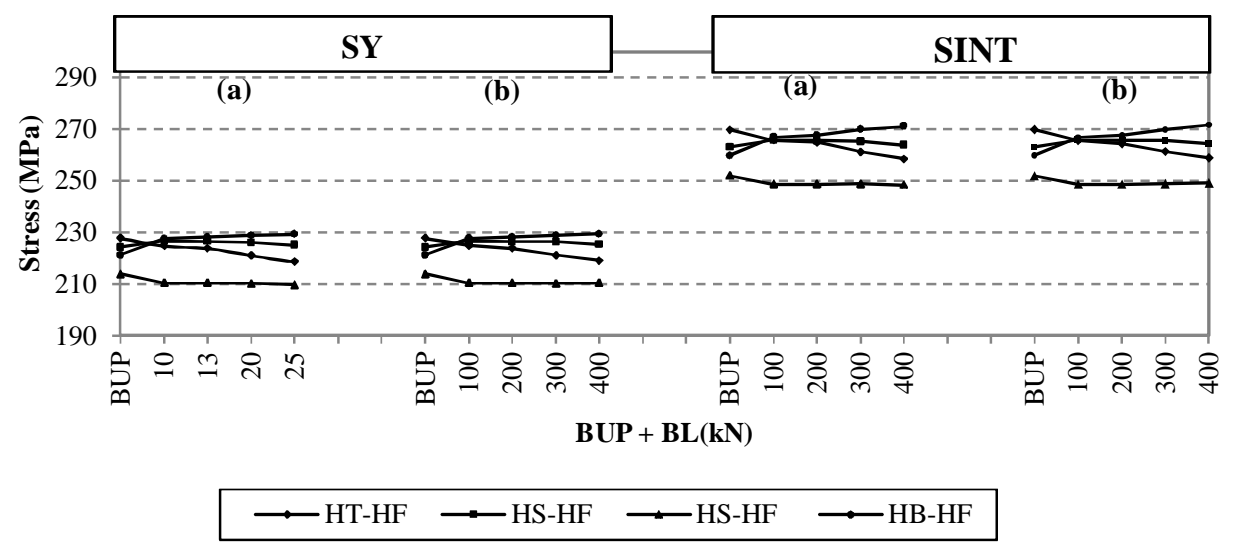

Fig. 5: Stresses (SY and SINT) results at the hub flange fillet under BUP and harmonic bending loading (10 25 kNm) of frequency: (a) $30 \mathrm{~Hz}$, (b) $60 \mathrm{~Hz}$.

\subsubsection{Harmonic Bending Loading only}

Figure 5 shows the stress results at the hub flange fillet location under harmonic bending loading. With the application of harmonic bending loading, some layers at the hub flange fillet location came under compression and others in tension. Values of stress at this location are already very high at bolt-up, so even after compression, no value of stress is 
negative. At $25 \mathrm{kNm}$ bending load, the axial stress at the top node of the hub-flange fillet has decreased from $228 \mathrm{MPa}$ at bolt-up to $219 \mathrm{MPa}$ and at the bottom node of the hubflange fillet, axial stress has increased from $221 \mathrm{MPa}$ at bolt-up to $229 \mathrm{MPa}$. Variation in the values of the resulting stresses due to change in the frequencies of the applied bending loads is negligibly small. Stress intensity at the top node of the hub-flange fillet decreased from $270 \mathrm{MPa}$ at bolt-up to $259 \mathrm{MPa}$ and at bottom node of hub-flange fillet, the principal stress increased from $260 \mathrm{MPa}$ at bolt-up to $271 \mathrm{MPa}$. Stress intensity at all nodes of the hub flange fillet is above the yield limit of the flange material. Summarizing, an increase in the magnitude of bending load has a small effect on the resulting stresses while increase in the cyclic frequencies of these loads has no prominent effect in this case.

\subsubsection{Internal Pressure plus Bending Loading}

Figure 6 shows the stress results at the hub flange fillet location under design pressure plus harmonic bending loading. Initially, with the application of internal pressure, the hub flange fillet came under tension but after the harmonic bending loading some of the layers at the hub flange fillet location came under compression. At $25 \mathrm{kNm}$ bending load, the axial stress has increased from $221 \mathrm{MPa}$ at bolt-up to $233 \mathrm{MPa}$. Variation in the values of the resulting stresses due to change in the frequencies of the applied bending loads is negligibly small. Stress intensity at hub-flange fillet has increased from 260MPa at bolt-up to $283 \mathrm{MPa}$. Stress intensity at all nodes of hub flange fillet is above yield limit of the flange material. Summarizing, an increase in the magnitude of harmonic bending load after internal pressure has a small effect on the resulting stresses while increase in the cyclic frequencies of these loads has no prominent effect in this case.

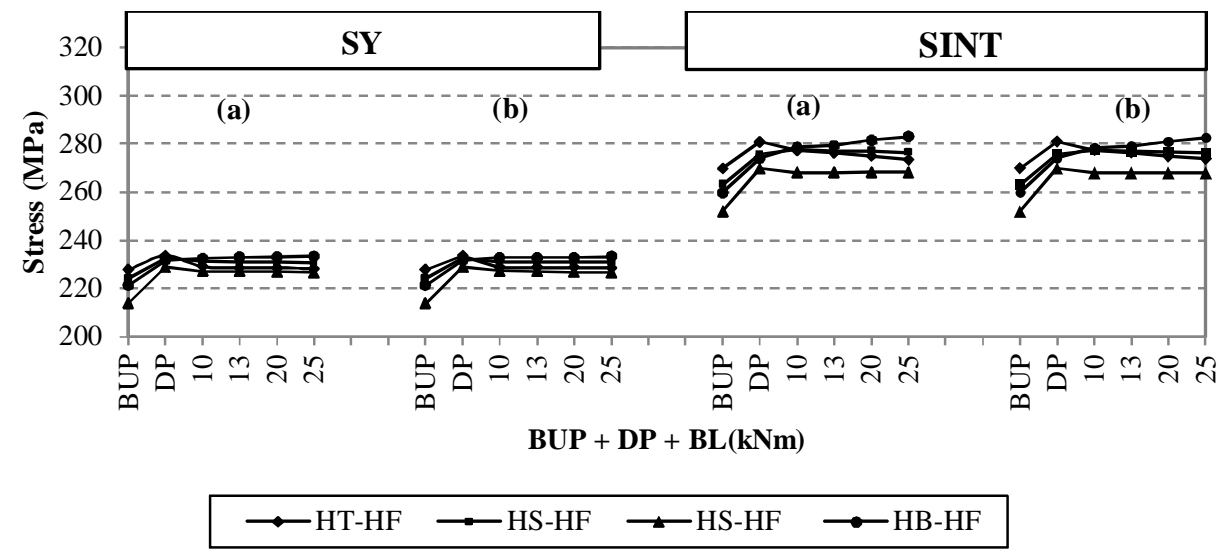

Fig. 6: Stresses (SY and SINT) results at the hub flange fillet under BUP, DP and harmonic bending loading (10 25 kNm) of frequency: (a) $30 \mathrm{~Hz}$, (b) $60 \mathrm{~Hz}$.

\subsubsection{Internal Pressure plus Combined Harmonic Axial Loading plus Harmonic Bending Loading}

Figure 7 shows the stress results at the hub flange fillet location under combined internal pressure plus harmonic axial $(525 \mathrm{kN})$ plus harmonic bending loading (10 20 $\mathrm{kNm})$. Axial stress has crossed the yield limit of the flange material at DP $+525 \mathrm{kN}$ external load. The value of the stress further increased with the application of internal pressure and harmonic axial loading. Further application of the combined internal pressure with harmonic axial and bending loadings has a very small effect on the resulting stress values. The maximum axial stress at the hub-flange fillet has increased from $263 \mathrm{MPa}$ and $265 \mathrm{MPa}$ at $\mathrm{DP}+525 \mathrm{kN}$ to $267 \mathrm{MPa}(1 \%)$ and $268 \mathrm{MPa}(1 \%)$ at the maximum external 
load of DP $+525 \mathrm{kN}+20 \mathrm{kNm}$ acting with a harmonic frequency of $30 \mathrm{~Hz}$ and $60 \mathrm{~Hz}$ respectively. The maximum value of the stress intensity at hub-flange fillet has increased from $311 \mathrm{MPa}$ and $312 \mathrm{MPa}$ at bolt-up to $312 \mathrm{MPa}$ and $313 \mathrm{MPa}$ at maximum external load of DP $+525 \mathrm{kN}+20 \mathrm{kNm}$ acting with a harmonic frequency of $30 \mathrm{~Hz}$ and $60 \mathrm{~Hz}$ respectively. Under combined external loadings, an increase in the values of the resulting stress is hardly $1 \%$ of those of DP $+525 \mathrm{kN}$. The increase in cyclic frequency has almost no effects on the stress values under all combined loadings.

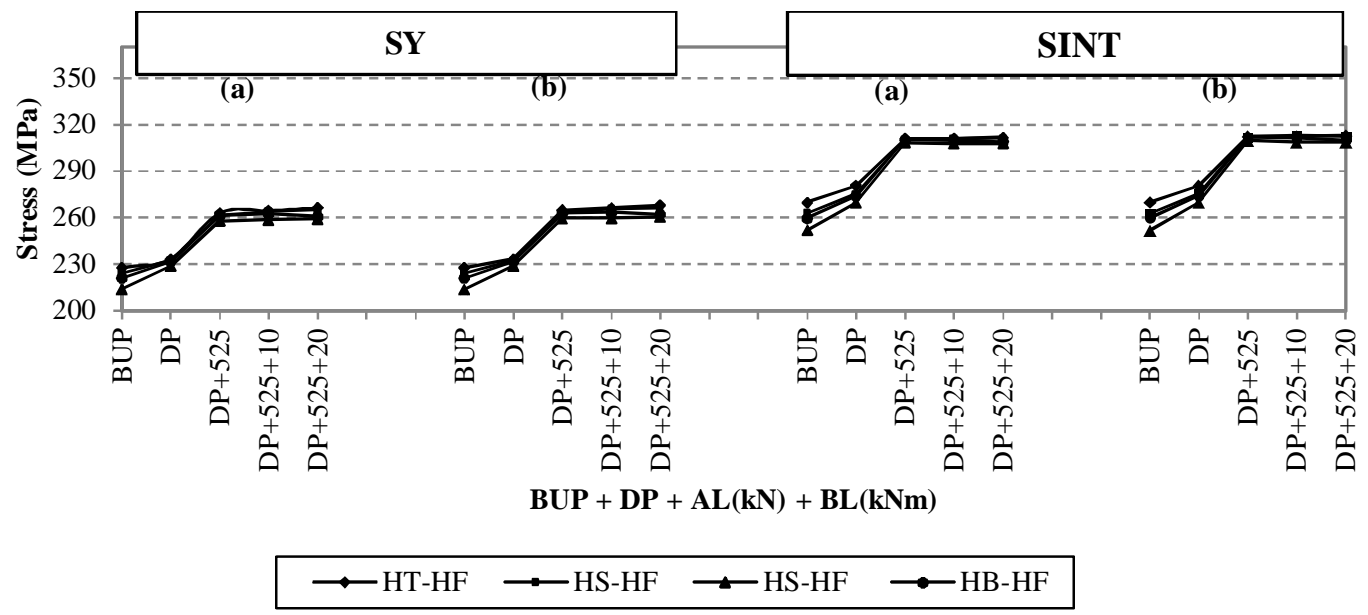

Fig. 7: Stresses (SY and SINT) results at the hub flange fillet under BUP, DP, harmonic axial loading (100 650 kN) and harmonic bending loading $(10 \sim 25 \mathrm{kNm})$ of frequency: (a) $30 \mathrm{~Hz}$, (b) $60 \mathrm{~Hz}$.

\subsection{Bolt Stress Variation}

\subsubsection{Harmonic Axial Loading only}

Figure 8 shows the average axial stress results at the mid node gauge of each bolt under BUP and axial loads $(100 \sim 650 \mathrm{kN})$ acting harmonically with two different frequencies $30 \mathrm{~Hz}$ and $60 \mathrm{~Hz}$. The values of axial stress in bolts increase linearly with the increase in magnitude of axial load and cyclic frequency of the loads. However all resulting stresses are under the yield limit of the bolt material. At an axial load of $650 \mathrm{kN}$ acting harmonically with frequency $30 \mathrm{~Hz}$ and $60 \mathrm{~Hz}$, the average increase in axial stress at each bolt of the joint is almost $45 \%$ and $65 \%$ more than the BUP respectively.

\subsubsection{Internal Pressure plus Harmonic Axial Loading}

Figure 9 shows the average axial stress results at the mid node gauge of each bolt under BUP, DP and axial loads $(100 \sim 650 \mathrm{kN})$ acting harmonically with two different frequencies of $30 \mathrm{~Hz}$ and $60 \mathrm{~Hz}$. At an axial load of $650 \mathrm{kN}$ acting harmonically with frequencies of $30 \mathrm{~Hz}$ and $60 \mathrm{~Hz}$, the average increase in axial stress at each bolt of the joint is almost $59 \%$ and $60 \%$ more than the BUP respectively.

\subsubsection{Harmonic Bending Loading only}

Figure 10 shows the average axial stress results at the mid node gauge of each bolt under BUP and bending loads $(10 \sim 25 \mathrm{kNm})$ acting harmonically with two different frequencies $30 \mathrm{~Hz}$ and $60 \mathrm{~Hz}$. Overall four bolts (Bolt 1, 2, 3 and 8) came under tension while remaining four bolts (Bolt 4, 5, 6 and 7) came under compression. The value of axial 
stress in the bolts either increased or decreased linearly with the increase in magnitude of the harmonic bending load. At bending load of $25 \mathrm{kNm}$ acting harmonically with any frequency, the variation in axial stress at bolts is 0 to $5 \%$ of BUP values.

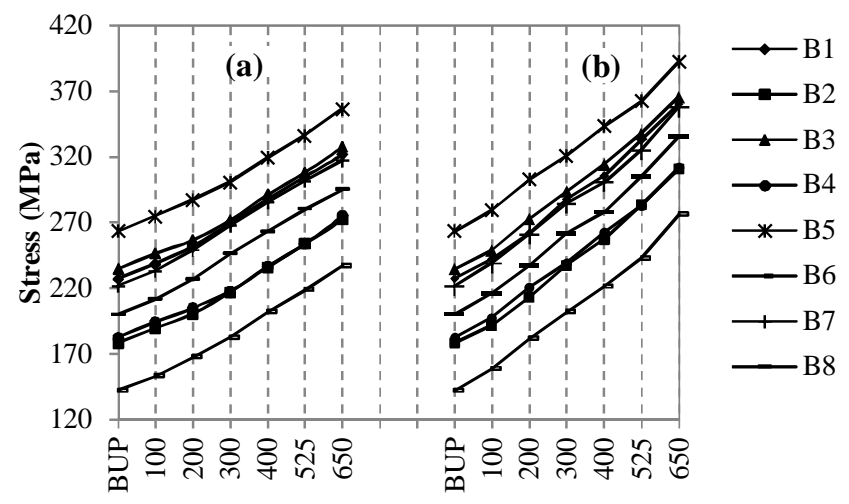

Fig. 8: Average bolt stress variation under bolt-up and harmonic axial loading $(100 \sim 650 \mathrm{kN}$ ) at frequency of: (a) $30 \mathrm{~Hz}$, (b) $60 \mathrm{~Hz}$.

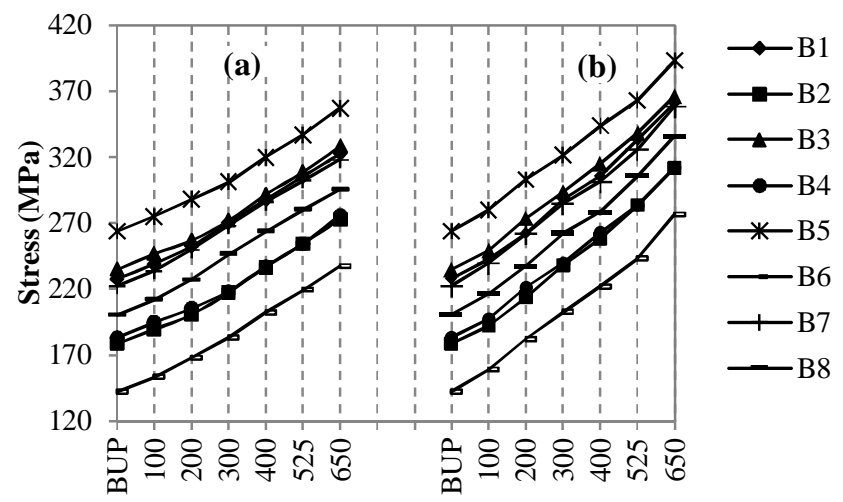

Fig. 9: Bolt average stress variation under BUP, DP and harmonic axial loading $(100 \sim 650 \mathrm{kN}$ ) at frequency of: (a) $30 \mathrm{~Hz}$, (b) $60 \mathrm{~Hz}$.

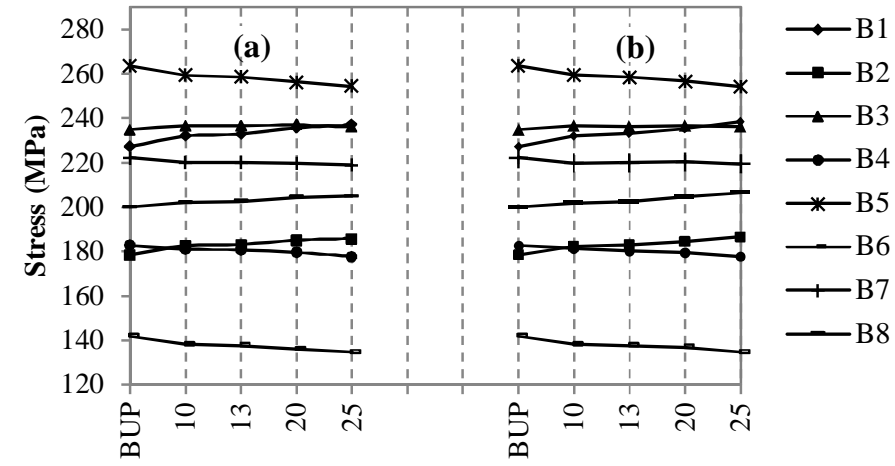

Fig. 10: Bolt average stress variation under bolt-up and harmonic bending loading (10 25 kNm) at frequency of: (a) $30 \mathrm{~Hz}$, (b) $60 \mathrm{~Hz}$.

\subsubsection{Internal Pressure plus Harmonic Bending Loading}

Figure 11 shows the average axial stress results at mid node gauge of each bolt under BUP, internal pressure and bending loads $(10 \sim 25 \mathrm{kNm})$ acting harmonically with two 
different frequencies of $30 \mathrm{~Hz}$ and $60 \mathrm{~Hz}$. After the application of internal pressure all bolts came in tension but the after the application of harmonic bending loading, overall four bolts (Bolt 1, 2, 3 and 8) come under tension while remaining four bolts (Bolt 4, 5, 6 and 7) come under compression. At a bending load of $25 \mathrm{kNm}$ acting harmonically with any frequency, the variation in axial stress at the bolts is almost 1 to $12 \%$ of that of BUP values.

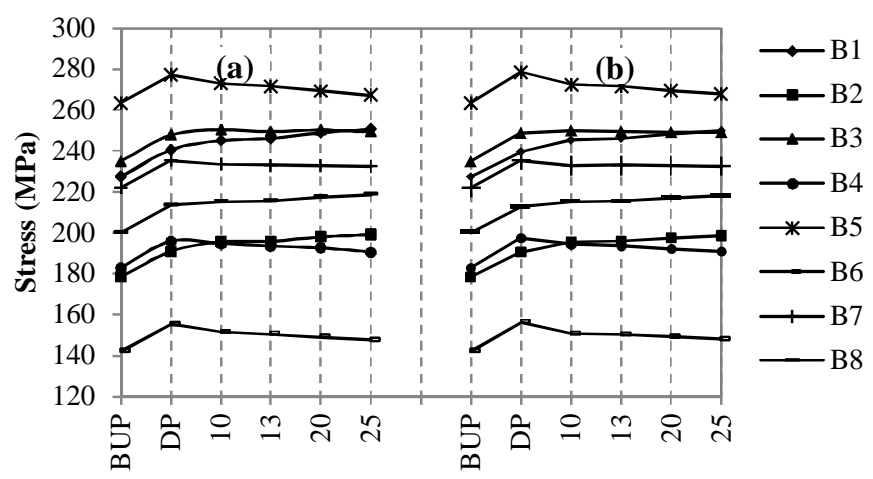

Fig. 11: Bolt average stress variation under BUP, DP and harmonic bending loading (10 25 kNm) of frequency: (a) $30 \mathrm{~Hz}$, (b) $60 \mathrm{~Hz}$.

\subsubsection{Internal Pressure plus Combined Harmonic Axial Loading plus Harmonic Bending Loading}

Figure 12 shows the average axial stress results at the mid node gauge of each bolt under internal pressure plus combined harmonic axial $(525 \mathrm{kN})$ loading plus harmonic bending loading (10 20 kNm). Initially, values of axial stress in bolts increase linearly with the increase in magnitude of axial load and cyclic frequency of the loads. But after applying bending loads in combination to the harmonic axial loads, the increase in axial stress has become calmer. At combined loads of DP $+525 \mathrm{kN}+20 \mathrm{kNm}$ acting harmonically with any frequency; the average increase in axial stress at any bolt of the joint is up to $2 \%$ of DP $+525 \mathrm{kN}$.

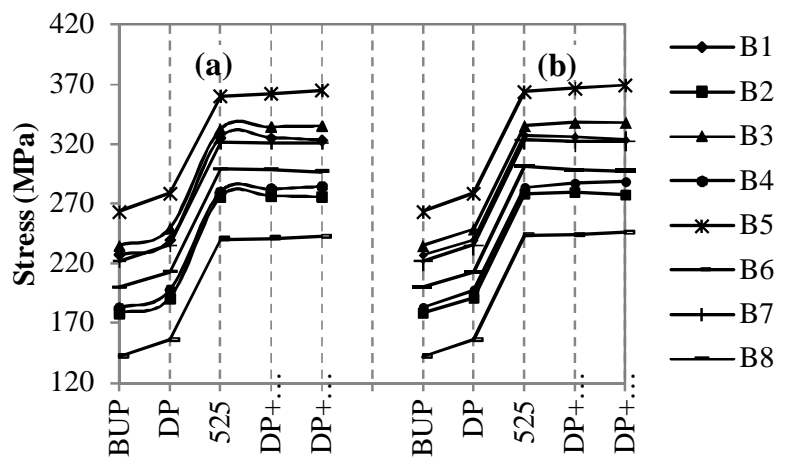

Fig. 12: Bolt average stress variation under BUP, DP, harmonic axial loading (100 650 $\mathrm{kN}$ ) and harmonic bending loading (10 25 kNm) at frequency of: (a) $30 \mathrm{~Hz}$, (b) $60 \mathrm{~Hz}$. 


\subsection{Gasket Stress Variation}

Nodes on the gasket (outer and inner) sealing ring corresponding to the bolt location are selected to study the contact stress variation with the tightening of each bolt and observe the effect of bolt scatter on the sealing performance.

\subsubsection{Harmonic Axial Loading only}

Figures 13 and 14 show gasket stress variation at inside and outside sealing ring diameter respectively, under BUP and axial loading $(100 \sim 650 \mathrm{kN})$ acting harmonically at two different frequencies of $30 \mathrm{~Hz}$ and $60 \mathrm{~Hz}$. At both the locations, under BUP and almost all axial loads and frequencies, the minimum gasket stress is observed at G6 (location of gasket near bolt number 6). An interesting behavior is seen in the gasket under harmonic axial loads. Initially, with the increase in axial harmonic loads, the compressive stress in the gasket decreased, but after increasing the load beyond $300 \mathrm{kN}$ with $30 \mathrm{~Hz}$ and $200 \mathrm{kN}$ with $60 \mathrm{~Hz}$ the compressive stresses in gasket started to increase. This is because the yielding started at the hub flange fillet location at $200 \mathrm{kN}$ load, and then the reverse loadings produced residual stresses in the gasket. It crushed the gasket, which was more dangerous for the sealing capability of the joint. The minimum compressive stress in the gasket at the inner sealing ring and outer sealing ring was -94 $\mathrm{MPa}$ and $-117 \mathrm{MPa}$ respectively. The seating stress recommended by the supplier was -68 MPa [17], which apparently shows the joint was safe against leakage, but actually the gasket might have been crushed and too weak to oppose leakage. Due to the increase in the cyclic frequency, the stress variation was about 0 to $15 \mathrm{MPa}$ from bolt-up.

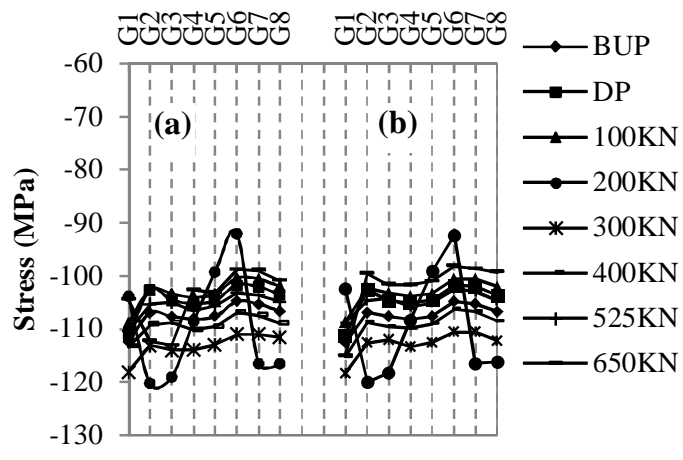

Fig. 13: Gasket contact stress variation at inner sealing ring under bolt-up and harmonic axial loading $(100 \sim 650 \mathrm{kN})$ at a frequency of: (a) $30 \mathrm{~Hz}$, (b) $60 \mathrm{~Hz}$.

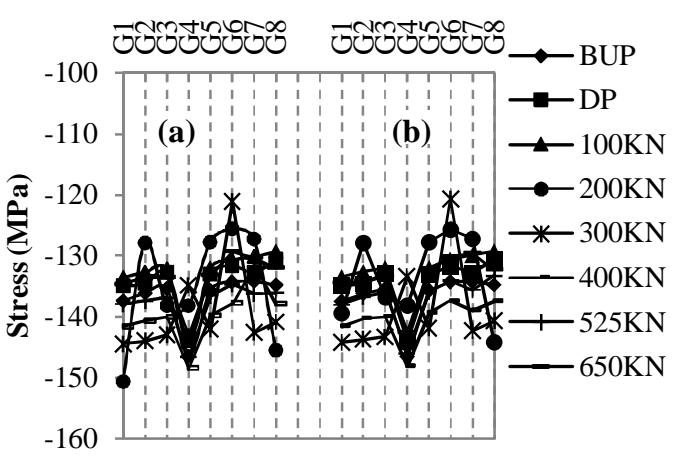

Fig. 14: Gasket contact stress variation at outer sealing ring under bolt-up and harmonic axial loading (100 650 kN) at a frequency of: (a) $30 \mathrm{~Hz}$, (b) $60 \mathrm{~Hz}$.

\subsubsection{Internal Pressure plus Harmonic Axial Loading}

Figures 15 and 16 show gasket stress variation at the inside and outside sealing ring diameter respectively, at BUP, DP and axial loading $(100 \sim 650 \mathrm{kN})$ acting harmonically at two different frequencies of $30 \mathrm{~Hz}$ and $60 \mathrm{~Hz}$. At both locations, the minimum gasket stress was observed at G6 (location of gasket near bolt number 6). With the increase in axial harmonic loads the compressive stress in the gasket was decreasing but at some loads (e.g. $300 \mathrm{kN}$ and $400 \mathrm{kN}$ with $30 \mathrm{~Hz}$ and $60 \mathrm{~Hz}$ frequencies respectively) the compressive stress was increasing at some gasket locations because the residual stresses induced reverse loading. It may have crushed the gasket, which was more dangerous for the sealing 
capability of the joint. The minimum compressive stress in the gasket at the inner sealing ring and outer sealing ring was $-92 \mathrm{MPa}$ and $-122 \mathrm{MPa}$ respectively. Variation of stress by varying cyclic frequency was between $0 \mathrm{MPa}$ to $12 \mathrm{MPa}$.

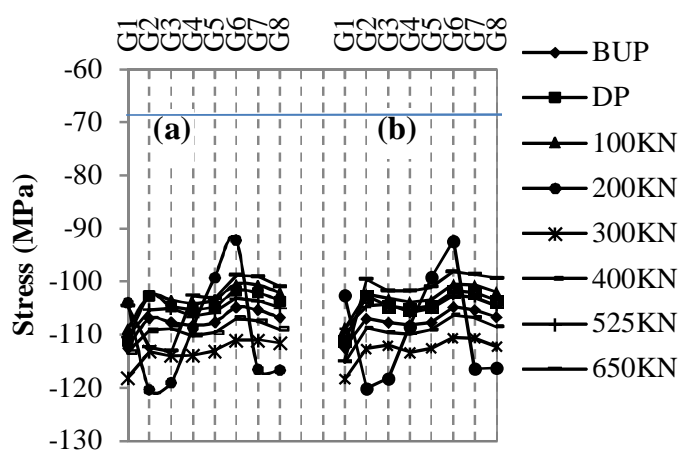

Fig. 15: Gasket contact stress variation at inner sealing ring under bolt-up and harmonic axial loading $(100 \sim 650 \mathrm{kN})$ at a frequency of:

(a) $30 \mathrm{~Hz}$, (b) $60 \mathrm{~Hz}$.

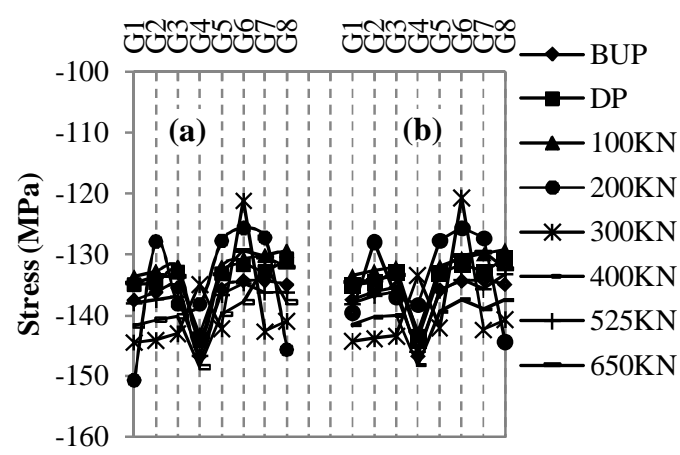

Fig. 16: Gasket contact stress variation at outer sealing ring under bolt-up and

harmonic axial loading $(100 \sim 650 \mathrm{kN})$ at a frequency of: (a) $30 \mathrm{~Hz}$, (b) $60 \mathrm{~Hz}$.

\subsubsection{Harmonic Bending Loading only}

Figures 17 and 18 show gasket stress variation at the inside and outside sealing ring diameter respectively, at BUP and bending loading $(10 \sim 25 \mathrm{kNm})$ acting harmonically at two different frequencies of $30 \mathrm{~Hz}$ and $60 \mathrm{~Hz}$. At the inner sealing ring diameter, the minimum gasket stress was observed at G2 and G6 (gasket locations near bolts number 2 \& 6). At the outer sealing ring, the minimum gasket stress was observed at G6 and G8 (gasket locations near bolts number $6 \& 8$ ). Variation of gasket contact stress was small with increase in bending loads and their frequencies. The minimum compressive stress in the gasket at the inner and outer sealing rings was -105 MPa and -133 MPa respectively. Hence the joint was almost safe against leakage.

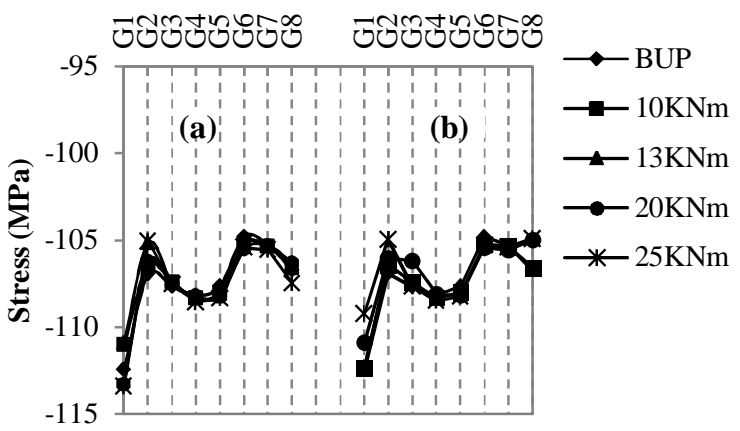

Fig. 17: Gasket contact stress variation at inner sealing ring under BUP and harmonic bending loading $(10 \sim 25 \mathrm{kNm})$ at a frequency of: (a) $30 \mathrm{~Hz}$, (b) $60 \mathrm{~Hz}$.

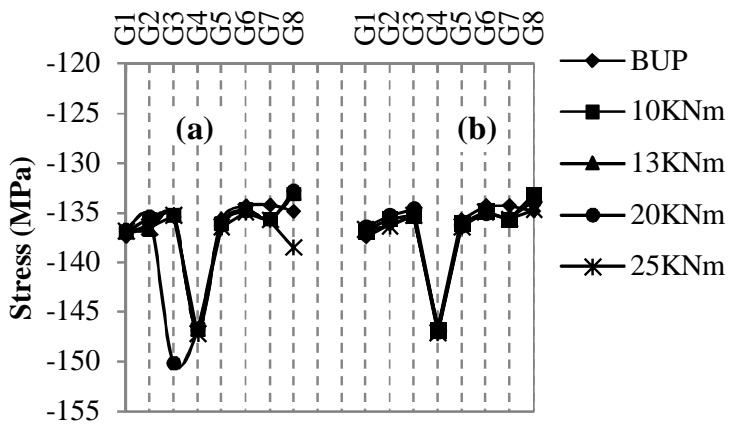

Fig. 18: Gasket contact stress variation at outer sealing ring under BUP and harmonic bending loading (10 25 $\mathrm{kNm})$ at a frequency of: (a) $30 \mathrm{~Hz}$, (b) $60 \mathrm{~Hz}$. 


\subsubsection{Internal Pressure plus Harmonic Bending Loading}

Figures 19 and 20 show gasket stress variation at the inside and outside sealing ring diameters respectively, at BUP, DP and harmonic bending loading $(10 \sim 25 \mathrm{kNm})$ with frequencies $30 \sim 60 \mathrm{~Hz}$. At the inner sealing ring diameter, the minimum gasket stress was observed at G6 (gasket location near bolt number 6). At the outer sealing ring, the minimum gasket stress was observed at G8 (gasket location near bolt number 8). In contrast to the results of previous case (only harmonic bending loading), the gasket stress values in this case were sufficiently below BUP and the main reason for this was the application of internal pressure. Variation of the gasket stress under different harmonic bending loads was again very small. The minimum compressive stress in the gasket at the inner and outer sealing rings was -102 MPa and -130 MPa respectively. Hence the joint was almost safe against leakage.

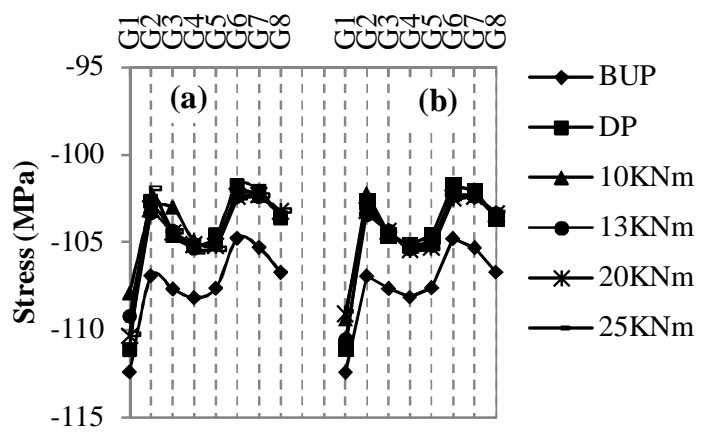

Fig. 19: Gasket contact stress variation at inner sealing ring under BUP, DP and harmonic bending loading $(10 \sim 25 \mathrm{kNm})$ at a frequency of: (a) $30 \mathrm{~Hz}$, (b) $60 \mathrm{~Hz}$.

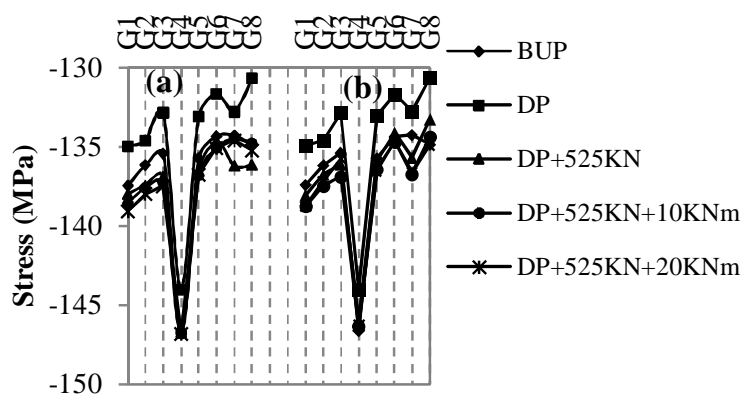

Fig. 21: Gasket contact stress variation at inner sealing ring under BUP, DP, harmonic axial loading $(100 \sim 650 \mathrm{kN})$ and harmonic bending loading $(10 \sim 25 \mathrm{kNm})$ at a frequency of: (a) $30 \mathrm{~Hz}$, (b) $60 \mathrm{~Hz}$.

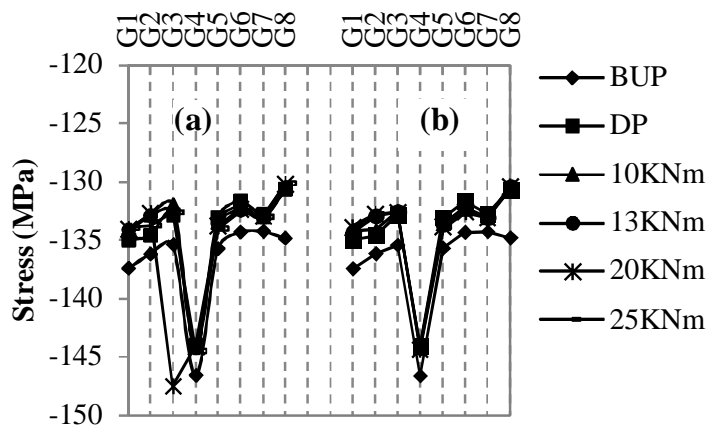

Fig. 20: Gasket contact stress variation at outer sealing ring under BUP, DP and harmonic bending loading $(10 \sim 25 \mathrm{kNm})$ at a frequency of: (a) $30 \mathrm{~Hz}$, (b) $60 \mathrm{~Hz}$.

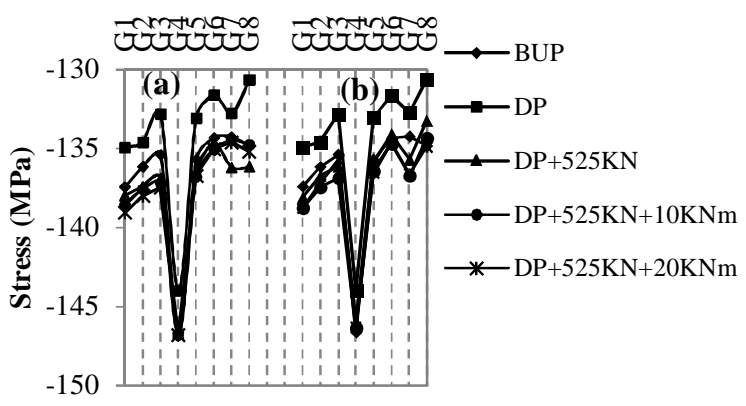

Fig. 22: Gasket contact stress variation at outer sealing ring under BUP, DP, harmonic axial loading (100 650 kN) and harmonic bending loading (10 25 kNm) at a frequency of: (a) $30 \mathrm{~Hz}$, (b) $60 \mathrm{~Hz}$.

\subsubsection{Internal Pressure plus Combined Harmonic Axial Loading plus Harmonic Bending Loading}

Figures 21 and 22 show the gasket stress variation at the inside and outside sealing ring diameter respectively, at BUP, DP and combined harmonic axial $(525 \mathrm{kN})$ and 
bending loading $(10 \sim 20 \mathrm{kNm})$ acting at two different frequencies of $30 \mathrm{~Hz}$ and $60 \mathrm{~Hz}$. At the inside sealing ring diameter, under all loadings and frequencies, the minimum gasket stress was observed at G6 (gasket location near bolt number 6), while at the outside diameter, the minimum stress was observed at G8 (gasket location near bolt number 8). More contact stress was found under higher combined loads. The reason for this was that the plasticity started at the flange. This stress was dangerous for the gasket and crushed it. The minimum compressive stress in the gasket at the inside and outside sealing ring diameter was -102 MPa and -131 MPa respectively. Outwardly, it looked safe for the seal on the basis of seat stress, but actually, the gasket was crushed, increasing the chances of leakage. The variation of the stress by varying cyclic frequency was very small.

\subsection{Displacement versus Time at Flange}

The graph is plotted for a time of 5 seconds when the joint was under external vibration loads only. The plots are typical sinusoidal curves showing the vibration behavior of the flange. Higher axial loads and higher cyclic frequencies have resulted in maximum amplitudes.

\subsubsection{Harmonic Axial Loading only}

Figure 23 shows the displacement history of the flange innermost location during vibrating axial loads $(100 \sim 650 \mathrm{kN})$ with two different cyclic frequencies $(30 \sim 60 \mathrm{~Hz})$. The flange joint was under continuous tension and compression loads, but the tension was dominant. The amplitude of the curve was changing in every other cycle and the reason was that the plasticity started at the flange. Maximum amplitude in case of $30 \mathrm{~Hz}$ cyclic frequency was $-0.25516 \mathrm{~mm}$ (at time step 4.5 ) and in case of $60 \mathrm{~Hz}$ cyclic frequency was $-0.24764 \mathrm{~mm}$ (at time step 2.5), which was initially $-0.4 \mathrm{~mm}$ at BUP. The behavior of the flange displacement under harmonic loads was the fatigue phenomenon which may cause failure at any time step later on. Generally, the maximum values found under harmonic axial loads had little difference to those found under equivalent static loads but the actual problem was the fluctuation of stresses and displacements with time under harmonic loads which is called fatigue and therein lies the real challenge.

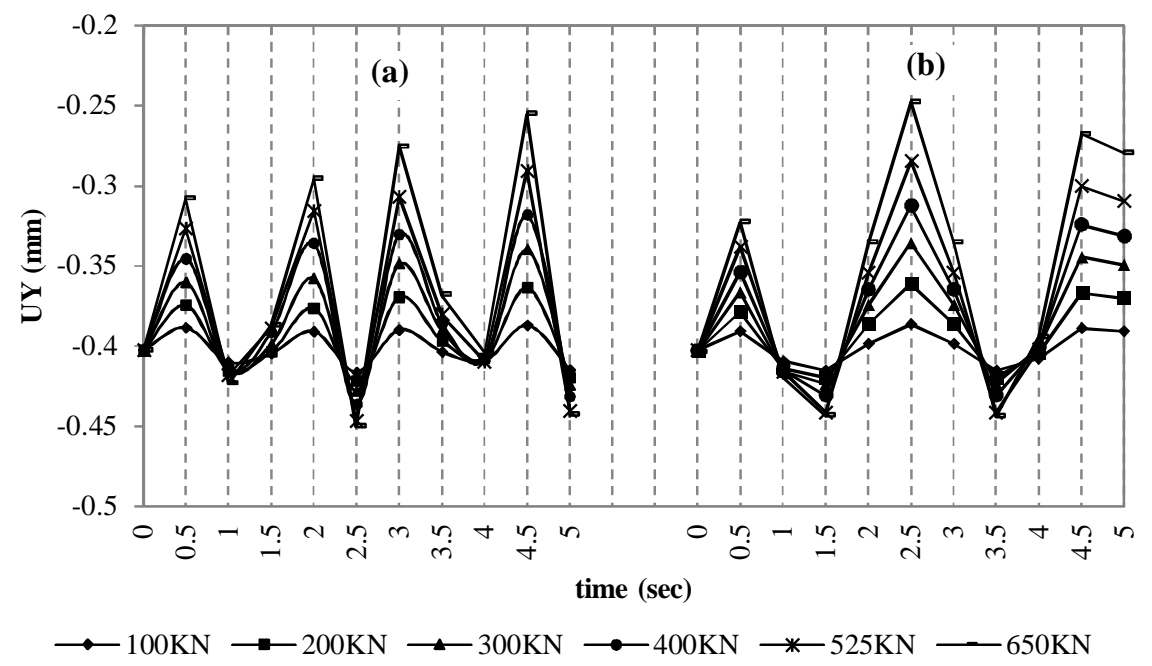

Fig. 23: Flange raised face displacement versus time under harmonic axial loading $(100 \sim 650 \mathrm{kN}$ ) at a frequency of: (a) $30 \mathrm{~Hz}$, (b) $60 \mathrm{~Hz}$. 


\subsubsection{Internal Pressure plus Harmonic Axial Loading}

Figure 24 shows the displacement history of the flange innermost location at DP and during the vibrating axial loads $(100 \sim 650 \mathrm{kN})$ with two different cyclic frequencies $(30 \sim 60 \mathrm{~Hz})$. Higher axial loads and higher cyclic frequencies resulted in maximum amplitudes. Maximum amplitude in the case of $30 \mathrm{~Hz}$ cyclic frequency was $-0.26494 \mathrm{~mm}$ (at time step of 3.5 seconds) and in case of $60 \mathrm{~Hz}$ cyclic frequency it was $-0.26274 \mathrm{~mm}$ (at time step of 1.5 seconds), which was initially $-0.4 \mathrm{~mm}$ at BUP plus DP. Again, tension was dominant over compression and the maximum amplitude was in the form of tension. Plasticity produced in the flange was the reason for the difference in the amplitude of different cycles.

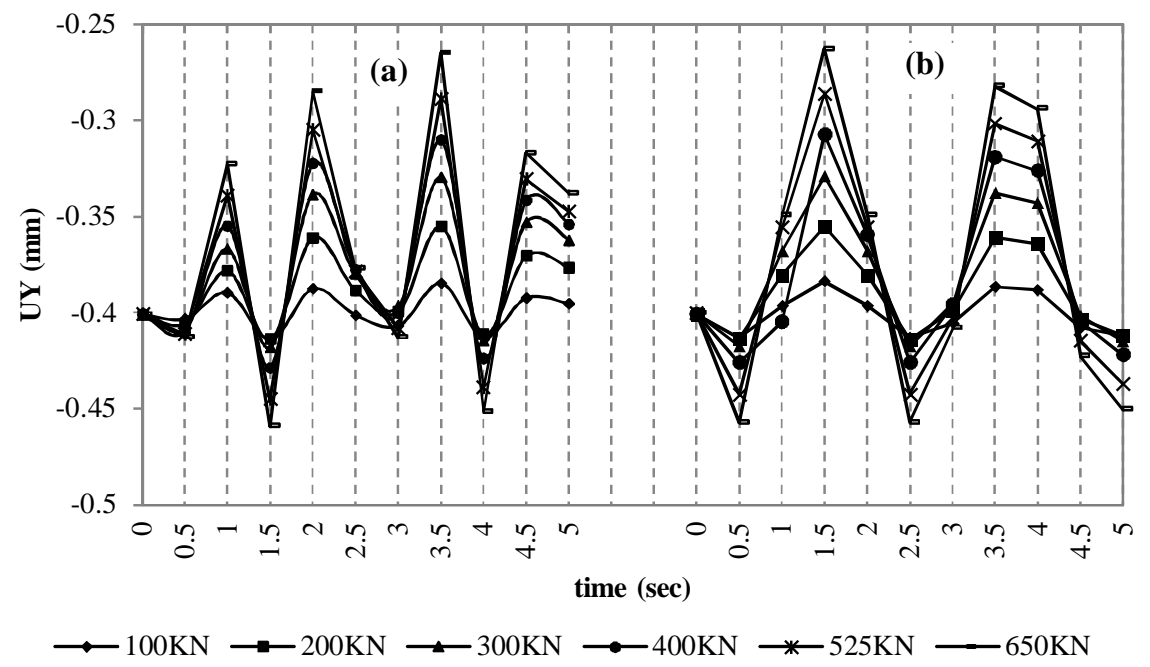

Fig. 24: Flange raised face displacement versus time under DP and harmonic axial loading $(100 \sim 650 \mathrm{kN}$ ) at a frequency of: (a) $30 \mathrm{~Hz}$, (b) $60 \mathrm{~Hz}$.

\subsubsection{Harmonic Bending Loading only}

Figure 25 shows the displacement history of the flange innermost location during the vibrating bending loads $(10 \sim 25 \mathrm{kNm})$ with two different cyclic frequencies $(30 \sim 60 \mathrm{~Hz})$. Maximum amplitude under both frequencies was almost same but the trend during the time of vibration was different, which showed the effect of frequency change during the fatigue period. The overall amplitude of the displacement was too low in this case in comparison to the previous two cases of axial loading. The maximum amplitude in case of $30 \mathrm{~Hz}$ cyclic frequency was $-0.39978 \mathrm{~mm}$ (at time step of $4.5 \mathrm{sec}$ ) and in case of $60 \mathrm{~Hz}$ cyclic frequency was $-0.39913 \mathrm{~mm}$ (at time step of $0.4 \mathrm{sec}$ ), which was initially -0.403 $\mathrm{mm}$ at BUP. The behavior of the flange displacement under harmonic loads was the fatigue phenomenon, which may cause failure of at any time step later on.

\subsubsection{Internal Pressure plus Harmonic Bending Loading only}

Figure 26 shows the displacement history of the flange innermost location at DP during the vibrating bending loads $(10 \sim 25 \mathrm{kNm})$ with two different cyclic frequencies (30 60 Hz). Maximum amplitude under both frequencies was almost same but the trend during the time of vibration was different, which showed the effect of frequency change during the fatigue period. The overall amplitude of displacement was too low in this case 


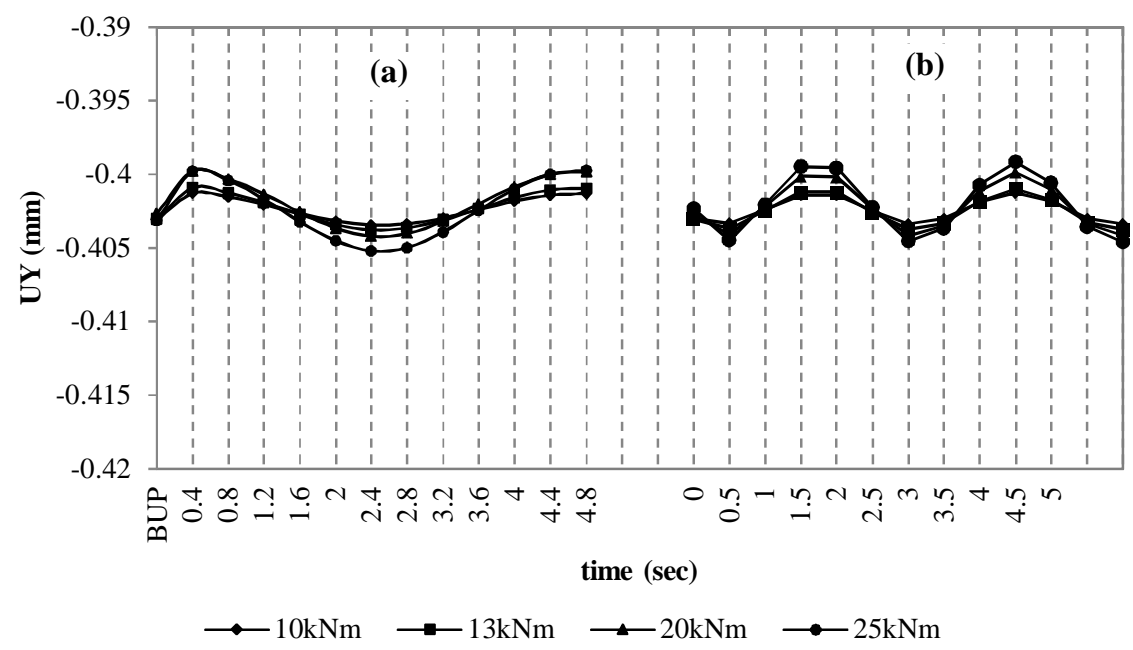

Fig. 25: Flange raised face displacement versus time under harmonic bending loading (10 25 kNm) at a frequency of: (a) $30 \mathrm{~Hz}$, (b) $60 \mathrm{~Hz}$.

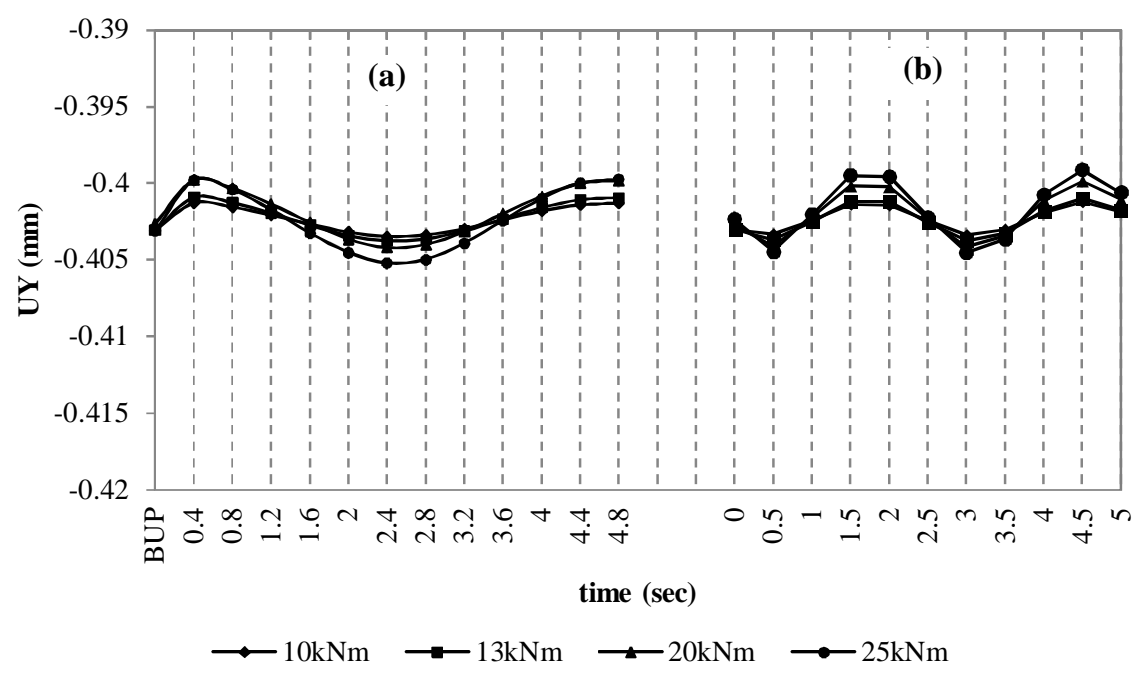

Fig. 26: Flange raised face displacement versus time under DP and harmonic bending loading (100 650 kN) at a frequency of: (a) $30 \mathrm{~Hz}$, (b) $60 \mathrm{~Hz}$.

in comparison to the axial loading cases. Maximum amplitude in the case of $30 \mathrm{~Hz}$ cyclic frequency was $-0.38558 \mathrm{~mm}$ (at time step of $1.5 \mathrm{sec}$ ) and in case of $60 \mathrm{~Hz}$ cyclic frequency was $-0.38586 \mathrm{~mm}$ (at time step of $2.5 \mathrm{sec}$ ) which was initially $-0.389 \mathrm{~mm}$ after the application of internal pressure. The behavior of the flange displacement under harmonic loads was the fatigue phenomenon, which may cause failure of at any time step later on.

\subsubsection{Internal Pressure plus Combined Harmonic Axial Loading plus Harmonic Bending Loading}

Figure 27 shows the displacement history of the flange innermost location under DP and combined DP and harmonic axial $(525 \mathrm{kN})$ and bending loadings $(10 \sim 20 \mathrm{kNm})$ with two different cyclic frequencies $(30 \sim 60 \mathrm{~Hz})$. Combined DP plus harmonic axial and bending loadings had almost the same resulting displacement values as those of DP plus 
harmonic axial loading. It showed that the combined internal pressure plus harmonic axial and bending loadings have no more effect than the combined DP plus axial loading. Maximum amplitude in the case of $30 \mathrm{~Hz}$ cyclic frequency was $-0.29132 \mathrm{~mm}$ (at time step $3.5 \mathrm{sec}$ ) and in case of $60 \mathrm{~Hz}$ cyclic frequency was $-0.28736 \mathrm{~mm}$ (at time step $1.5 \mathrm{sec}$ ) which was initially $-0.38 \mathrm{~mm}$ at DP. The behavior of the flange displacement under harmonic loads was the fatigue phenomenon which may cause failure at any time step later on.

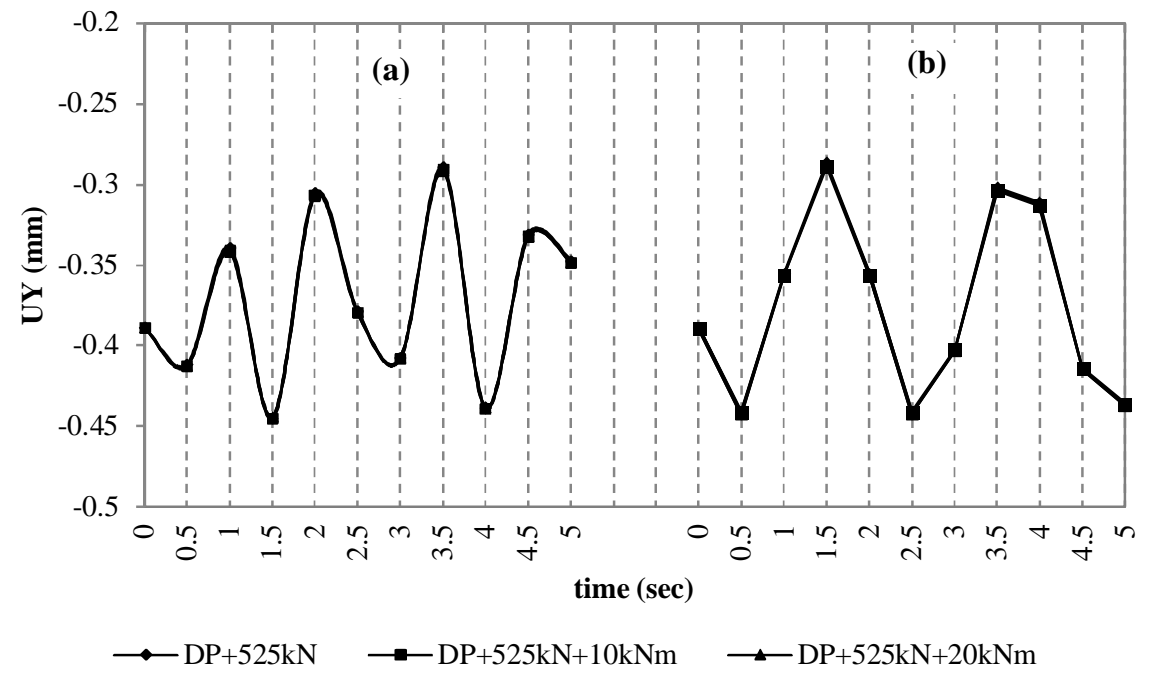

Fig. 27: Flange raised face displacement versus time under harmonic axial loading $(100 \sim 650 \mathrm{kN}$ ) at a frequency of: (a) $30 \mathrm{~Hz}$, (b) $60 \mathrm{~Hz}$.

\section{CONCLUSION}

- In harmonic analysis, axial loadings are concluded to be more critical over bending loadings in addition to internal pressure. At the hub flange fillet location, stress values have exceeded the yield limit $(250 \mathrm{MPa})$ of flange material, which is a risk to the mechanical strength of the joint. Reverse loadings after the yield limit are producing residual stress in the gasket, which crushes the gasket and increases the chances of leakage.

- In the case of harmonic axial loads plus internal pressure, the stress values increase about $19 \%$ at the hub flange fillet location, and $60 \%$ at the bolts, which is a sign of risk to the joint strength.

- Combinations of harmonic loads and internal pressure produce lesser stresses and displacements in comparison to single harmonic loads. This is because combined loads damp out each other's effects.

- Higher amplitudes of harmonic loads and higher frequencies result in more stresses and displacements, hence a greater risk to the joint strength and sealing capability. On the other hand, lower frequencies cause a greater number of fatigue cycles in the same vibration time interval, which is also a risk for sealing.

- In all cases, the gasket stresses were above the recommended seating stress of -68 $\mathrm{MPa}$, which showed that the gasket was crushed and this would affect the sealing capability of the joint. 
- In the case of harmonic axial loads plus internal pressure, an average maximum displacement of $-0.26 \mathrm{~mm}$ was produced at the flange raised face, which was initially $-0.4 \mathrm{~mm}$ at BUP plus internal pressure. This change in displacement showed flange rotation, which is responsible for producing a gap between the two flanges at the contact faces. Hence, there was a chance of leakage.

\section{REFERENCES}

[1] Gaul L, Lenz J. (1997) Nonlinear dynamics of structures assembled by bolted joints. Acta Mechanica, 125(1-4):169-181.

[2] Ibrahim RA, Pettit CL. (2005) Uncertainties and dynamic problems of bolted joints and other fasteners. J. Sound and Vibration, 279:857-936.

[3] Jalali H, Ahmadian H, Mottershead JE. (2007) Identification of nonlinear bolted lap-joint parameters by force-state mapping. Int. J. Solids and Structures, 44:8087-8105.

[4] Khan NB. (2009) Stamina of Gasketed Pipe Flange Joint under Combined Loading: 3D FEA Study. MS thesis, GIK Institute of Engineering Sciences and Technology. Topi, Pakistan.

[5] Lina T, Lia R, Long H, Ou H. (2006) Three-dimensional transient sealing analysis of the bolted flange connections of reactor pressure vessel. Nuc. Eng. Design, 236(24):2599-2607.

[6] Luan Y, Guan Z, Cheng G. (2010) The study on nonlinear dynamic behaviors of the structures with bolted-flange joint. IOP Conf. Series: Materials Science and Engineering, 112.

[7] Miller HL. (2001) Piping Vibration Involving Control Valves. Int. Joint Generation Conference and Exposition ASME International - Power Division, 1-11.

[8] Ouyang H, Oldfield MJ, Mottershead JE. (2006) Experimental and theoretical studies of a bolted joint excited by a torsional dynamic load. Int. J. Mechanical Sciences, 48:1447- 1455.

[9] Semkea WH, Bibel GD, Jerath S, Guravb SB, Webster AL. (2006) Efficient dynamic structural response modelling of bolted flange piping systems. Int. J. Pressure Vessels and Piping, 83:767-776.

[10] Tanlak N, Sonmez F, Talay E. (2010) Detailed and simplified models of bolted joints under impact loading. The J. Strain Analysis for Engineering Design, 46(3):213-225.

[11] Abid M. (2000) Experimental and analytical studies of conventional (gasketed) and uncoventional (non gasketed) flanged pipe joints (with special emphasis on the engineering of 'joint strenght' and 'sealing'). PhD Thesis, University of strathclyde, Glasgow, UK.

[12] Wilcoxon Research. Pump monitoring with Wilcoxon piezoelectric accelerometers. http://www.wilcoxon.com. 2009.

[13] ANSYS Inc. (2011), ANSYS elements manual, 13th edition, ANSYS Inc.

[14] American Society of Mechanical Engineering (1998) ASME boiler and pressure vessel Code Section VIII, Part D. New York, USA.

[15] Nagata S, Shoji Y, Toshiyuki S. (2002) A simplified modeling of gasket stress-strain curve for fem analysis in bolted flange joint design. ASME International PVP Conference, BC Canada, 53-58.

[16] Abid M, Hussain S. (2007) Bolt preload scatter and relaxation behavior during tightening a 4 in-900\# flange joint with spiral wound gasket. Proc. IMech, 222(part E), J. Process Mechanical Engineering, 123-134.

[17] ASME PCC-1-2000. (2002) Guidelines for pressure boundary bolted flange joint assembly. An American National Standard.

\section{NOMENCLATURE}
$H F \quad$ Hub flange
$H B \quad$ Hub bottom
HS Hub side 


$\begin{array}{ll}H T & \text { Hub top } \\ B U P & \text { Bolt up } \\ S Y & \text { Bending stress } \\ \text { SINT } & \text { Stress intensity } \\ D P & \text { Design pressure } \\ A L & \text { Axial loading } \\ B L & \text { Bending loading } \\ F R Q & \text { Frequency }\end{array}$

